\title{
Wizja procedury cywilnej w uzasadnieniach i raportach do projektu Code de procédure civile z 1806 roku
}

Truizmem jest z pewnością wielokrotnie powtarzane przez barona Locré, sekretarza generalnego Rady Stanu, twierdzenie, iż aby znać prawo, nie wystarczy poznać jedynie jego tekst, konieczne jest odkrycie jego ducha, czyli uchwycenie motywów determinujących działania legislatora i celu, jaki mu przyświecał. „Któż może bowiem lepiej wyjaśnić intencje ustawodawcy niż on sam?” - pytał retorycznie. „I jak też nie odkryć jego intencji - dodawał kiedy w przeprowadzanych na jego oczach pracach przygotowawczych, śledzić możemy wszystkie transformacje jego myśli aż do formy, którą finalnie przybrały?"1

$\mathrm{Na}$ mocy rozporządzenia konsularnego z 3 germinala roku X (24 marca 1802) powołana została komisja mająca za zadanie opracowanie projektu kodeksu procedury cywilnej. W jej skład wchodzili: J.B. Treilhard, Try², P. Bertherau, A.J. Séguier, E.N. Pigeau i J. Fondeur jako sekretarz. W wyniku jej prac powstała wersja, która, opatrzona uwagami wstępnymi sporządzonymi przez J.B. Treilharda (co wskazuje na jego główną rolę przy opracowywaniu pierwotnej wersji projektu), została następnie opublikowana i rozesłana do sądów i trybunałów z prośbą o opinię. Te z kolei nanosiły na projekt swoje uwagi, trafiające do Sekcji Prawodawczej Rady Stanu, której członkami byli wówczas P.F. Réal, T. Berlier, J.J. Siméon, P. Galli i J.B. Treilhard, a przewodniczącym F.J. Bigot-Préameneu. Sekcja, formułując własne spostrzeżenia, przedkładała projekt pod obrady plenarne, z których sporządzano protokoły (procès-verbaux). Notabene dyskusja odbywająca się w Radzie Stanu została uznana przez barona J.G. Locré za najbardziej jałową w porównaniu do debat nad innymi kodeksami, a większość radców nie brała w niej w ogóle

${ }^{1}$ J.G. Locré, Esprit du Code de Procédure Civile ou Conférence du Code de Procédure avec les Discussions du Conseil, les Observations du Tribunat, les Exposés de motifs, les Discours des Orateurs du Tribunat, les Dispositions des autres Codes, etc., Paris 1816, t. I, s. XIV.

${ }^{2}$ Brak danych dotyczących imienia bądź imion. 
udziału $^{3}$. Na tym etapie Trybunat uprawniony był do zgłaszania swoich obserwacji (observations), odnotowywanych w protokołach, do których odnosiła się Rada Stanu, wypracowując swoje ostateczne stanowisko w postaci uzasadnień do projektu (exposés des motifs). Trybunat przeprowadzał nad nim dyskusję, formułując zsyntetyzowane wnioski w postaci raportów (raports), które następnie przedstawiane były przez jego członków Ciału Prawodawczemu. To gremium z kolei, po wysłuchaniu zarówno uzasadnień przedstawicieli Rady Stanu, jak i raportów członków Trybunatu, decydowało w głosowaniu tajnym o przyjęciu lub odrzuceniu projektu w całości już bez debaty, która nie leżała w gestii Ciała Prawodawczego. Exposés des motifs Rady i raporty Trybunatu stanowiły więc obok samego tekstu normatywnego końcowy produkt prac legislacyjnych. Przedstawiano w nich bowiem ostatecznie uzgodnioną wersję projektu przygotowaną do oficjalnej prezentacji ${ }^{4}$.

Code de procédure civile podzielony został na sześć odrębnych ustaw sukcesywnie uchwalanych od 14 do 29 kwietnia 1806 r. Każda z nich stanowiła przedmiot odrębnego uzasadnienia (exposé des motifs) sporządzonego przez wyznaczonych dla tej części radców stanu (jednego lub kilku). Ich redakcja została powierzona członkom Sekcji Prawodawczej Conseil d'État - „dawnym jurystom, których wiedza i doświadczenie" stanowiła - według słów członka Trybunatu L.J. Faure wyznaczonego do przedstawienia spostrzeżeń Trybunatu - „gwarancję najlepszych efektów"5. Byli to wspomniani J.B. Treilhard, F.J. Bigot-Préameneu, P.F. Réal, T. Berlier, J.J. Siméon i P. Galli. Podział pracy na sześć części i przyporządkowanie do każdej z nich odrębnego promotora (lub promotorów) powodowało, że siłą rzeczy poszczególne exposés des motifs dotyczyły tylko pewnego fragmentu całości i koncentrowały się przede wszystkim na uzasadnieniu rozwiązań szczegółowych. Wyjątek stanowiło jedynie exposé des motifs Jeana Baptiste Treilharda, które - jako że dotyczyło części pierwszej - w największym stopniu odnosiło się do przewodnich idei projektu. Jego głos miał szczególne znaczenie także z tego względu, że to on jako jedyny spośród promotorów projektu wyłonionych z Rady Stanu uczestniczył w przygotowaniu pierwotnego projektu, zanim tenże trafił pod obrady Conseil d'État. Niemniej jednak pozostałe wystąpienia również zasługują na

${ }^{3}$ J.G. Locré, Législation civile, commerciale et criminelle de la France, ou commentaire et complément des Codes Français, Paris 1827, t. I, s. 146.

${ }^{4}$ Senat Zachowawczy badał konstytucyjność ustawy jedynie na wniosek Trybunatu lub konsulów.

${ }^{5}$ „Le projet de Code de procédure a été rédigé par d'anciens jurisconsultes [...] dont les lumières et expérience garantissent les plus heureux résultats"; Rapport fait par M. Faure, orateur du Tribunat au nom de la Section de Législation sur le Livre I et les neuf premiers titres du Livre II du Projet de Code de Procédure Civile, séance du 14 avril 1806; wszystkie exposés des motifs i raporty były wielokrotnie publikowane, m.in. w cytowanym w przypisie nr 1 dziele barona Locré'a. Tu korzystano z wydania oficjalnego: Code de procédure civil, motifs et rapports, édition stéréotype faite au moyen de matrices mobiles en cuivre, procédé d'Herhan, Paris 1806, s. 168. 
uwagę. Także w nich można bowiem odnaleźć pewne wątki ogólnych idei, którymi - zgodnie z deklaracjami - kierowano się przygotowując projekt. Należy jednak zaznaczyć, że motywy prawodawcze zaprezentowane przez każdego z radców stanu osobno nie były w pełni ze sobą zharmonizowane i razem nie tworzyły spójnej całości.

Prezentowane przez członków Trybunatu raporty nie były w zakresie merytorycznym tożsame z uzasadnieniami Rady Stanu, omawianą bowiem materię podzielono na dziewięć przemówień, wygłaszanych kolejno przez L.J. Faure, C.F. Périna, J. Albissona, G.J. Favarda, J. Greniera, J.D.L. Tarrible, T.L. Mouricaulta, J.C.M. Gilleta i C.J. Mallarmé.

Znaczenie exposés i raportów było szczególnie doniosłe z uwagi na fakt, iż w samym kodeksie nie sformułowano żadnych zasad ogólnych. Z tego względu J.B. Treilhard zauważał: „Twierdzi się, że tok działania wytyczony dla każdego incydentu pozostawia coś do życzenia, ponieważ nie wspomina się tu dosłownie normy ogólnej, mogącej znaleźć zastosowanie w konkretnym przypadku"6. Niemniej jednak wyraźnie podkreślał on istnienie pewnych myśli przewodnich, idei podstawowych, które można wydedukować z treści normatywnej, zwłaszcza jeżeli przy analizie norm prawnych sięgnie się do wykładni autentycznej zawartej w exposés i raportach. Można zatem pokusić się o stwierdzenie, że przynajmniej w zamyśle ich autorów kodeks miał stanowić intelektualną konstrukcję opartą na kilku solidnych filarach, hołdując wyznaczonym przez nich celom ogólnym.

W pierwszej kolejności należy zauważyć, że w uzasadnieniach i raportach Code de procédure civile został zaprezentowany przede wszystkim jako niezbędne uzupełnienie ${ }^{7}$ dla Code civil $^{8}$. „Dla dobra ludu francuskiego”, twierdził J.B. Treilhard, ,dzieło to [Code civil-A. K.] winno być chronione przed zgubnymi skutkami interesowności oraz złej woli”’ . Członek Trybunatu L.J. Faure natomiast podnosił, iż ,[...] zgromadziwszy w jednym zbiorze praw całe nasze prawo cywilne, w innym zbiorze należało zgromadzić wszystkie praktyki

${ }^{6}$ „On prétend que la marche tracée sur chaque incident laisse quelque chose à désirer, parce qu'on n'y rappelle pas textuellement la règle générale qui peut recevoir son application dans le cas particulier"; Exposé de motifs des livres premier et deuxième de la première partie du Code de procédure civile présenté au Corps Législatif par M. Treilhard, Conseiller d'État, séance du 4 avril 1806, [w:] op. cit., s. 11.

${ }^{7}$ Podejście to podkreślał także baron Locré przy okazji wydania dokumentacji z prac legislacyjnych. Wyraźnie zaznaczał, iż cały system prawa zdefiniowany został w Code civil, natomiast Code de procédure civile przeznaczono jedynie do ustanowienia form niezbędnych do jego funkcjonowania w praktyce; J.G. Locré, Esprit..., t. I, s. XXI.

${ }^{8}$ Szerzej na temat Code civil: K. Sójka-Zielińska, Kodeks Napoleona. Historia i wspótczesność, Warszawa 2008, passim; idem, Wielkie kodyfikacje cywilne. Historia i wspótczesność, Warszawa 2009, s. 175-276.

9 „Il faut, pour le bonheur du peuple français que cet ouvrage soit protégé contre les effets artificieux de l'intérêt et de la mauvaise foi”; Exposé de motifs des livres premier..., [w:] op. cit., s. 2. 
konieczne do jego egzekucji” ${ }^{10}$. Radca stanu P. Galli dodawał jeszcze, że „nie wystarczy, by Państwo miało dobre prawa, trzeba również środków, aby ich egzekucja była sprawna"11. Afirmowano więc wyraźnie prymat materialnego prawa cywilnego, postrzeganego jako fundament wyznaczający normom procesowym rolę służebną.

Potrzeba opracowania ram proceduralnych zapewniających prawidłową egzekucję praw materialnych szczególnie jaskrawo uwidaczniała się na tle negatywnych doświadczeń okresu Rewolucji. Dowodzi tego kazus z nieumiejętnym wprowadzeniem postępowania arbitrażowego. Już w słynnej konstytucji roku I za zasadnicze uznano postępowanie arbitrażowe, a strony niemogące lub niechcące poddać się arbitrażowi z wyboru odsyłano przed arbitrów publicznych, zastępujących trybunały i orzekających w niektórych sprawach ${ }^{12}$ w charakterze ostatniej instancji „bez kosztów i procedury” " Konstytucja, co prawda, nigdy nie weszła w życie, niemniej jednak dnia 24 października 1793 r. (3 brumaire an II) wprowadzono dekret znoszący zastępców sądowych i redukujący procedurę sądową do postępowania arbitrażowego.

Wyraźnie odwołał się do tego J.B. Treilhard w swoim exposé de motifs:

„Gdybyśmy uwierzyli pewnym osobom, znieślibyśmy wszelki typ procedur, jak gdyby decyzji sędziów miała nie poprzedzać żadna instrukcja. Czy po próbie, jakiej ostatnio nas poddano, nadal można ulegać takiej przesadzie? Czy nie jest tak, że wszystkich adwokatów i całą procedurę zniesiono w napadzie, lub raczej delirium doskonałości? Co z tego wynikło?"14

\section{L.J. Faure dodawał:}

„Czyż wielowiekowa historia nie dowodzi, że tam, gdzie nie istnieją żadne formy, rządzi wyłącznie arbitralność, tam zaś, gdzie rządzi arbitralność, widać wyłącznie nieład i zamieszanie? Formy słowem jednym stanowią gwarancję stosowności i pewności"15.

$10,,[\ldots]$ après avoir réuni dans un recueil de lois tout notre droit civil, il convenait de réunir dans un autre recueil toutes les pratiques nécessaires à son exécution"; Rapport fait par M. Faure..., [w:] op. cit., s. 167.

${ }_{11}$ „Il ne suffit pas à un État d'avoir de bonnes lois, il faut aussi des moyens pour l'exécution en soit aisée"; Exposé de motifs du troisième et dernier livre de la deuxième partie du Code de procédure civile présenté au Corps Législatif par MM. Gally, Jaubert et Berlier, Orateurs du Conseil d'État, séance du 19 avril 1806, [w:] op. cit., s. 156.

12 J.G. Locré, Législation..., t. I, s. 142.

${ }^{13}$ Art. 94 Konstytucji z 1793 r.

14 „Si l'on en croyait certaines personnes, on supprimerait toute espèce de procédures, comme si la décision des magistrats pouvait n'être précédée d'aucune instruction [...] comment peut-on se livrer encore à ces exagérations, après l'épreuve récente que nous avons fait? N'a-t-on pas supprimé tous les avoués et toute la procédure dans un accès ou plutôt dans un délire de perfection? Qu'en est-il résulté?"; Exposé de motifs des livres premier..., [w:] op. cit., s. 12-13.

15 „L'histoire des siècles ne prouve-t-elle pas que là où les formes n'existent point, l'arbitraire seul règne, et que là où règne l'arbitraire, on ne voit que désordre et confusion? Les formes sont, 
Za niezwykle istotne uznano także zniesienie lokalnych partykularyzmów i wprowadzenie jednolitych reguł postępowania, co w zamyśle miało umożliwić sądom i trybunałom także harmonijne stosowanie prawa materialnego. „Czy często nie bagatelizowalibyśmy instrukcji, gdybyśmy nie nadawali jej stałego biegu, gwarantującego bezpieczeństwo od błędów i niespodzianek?"16 _ podnosił J.B. Treilhard. Procedura nie powinna być przy tym skomplikowana, a jej formy „podchwytliwe”. J.B. Treilhard wyraźnie podkreślał, iż „w naszym wieku procedura nie musi skrywać pułapki zastawionej na uczciwość, a pod panowaniem oświeconego ducha normy będą zawsze zgodne z rozumem"17. Zdaniem P. Galliego przede wszystkim ,należy zapobiec szykanom, przebiegłym sztuczkom tych, którzy mieliby interes w krępowaniu rozporządzeń prawa. Zbyt drobiazgowe, zbyt subtelne, zbyt długie formy nigdy nie są odpowiednie, więc należy je uprościć, usunąć, musi zatryumfować prostota" ${ }^{18}$.

Zgodni byli więc co do tego, że postępowanie powinno być proste, szybkie i ekonomiczne. W dyskursie między członkami Rady Stanu i Trybunatu dominowało przekonanie, że projekt wychodzi naprzeciwko tym oczekiwaniom. Radca stanu P. Galli radośnie obwieszczał: „tak, panowie, gwarantuję wam jasny i prosty kodeks prawny, wolny od wszelkiego gadulstwa i zbytecznych procedur" 19 . Wtórował mu członek Trybunatu J. Albisson, który, zachwalając dzieło kodyfikatorów, stwierdzał: „Uprościliście i przyspieszyliście bieg instrukcji”20. „Proste” i jego odmiany było zresztą najczęściej stosowanym w exposés i raportach przymiotnikiem kwalifikującym. Prostota stanowiła nawet swoisty leitmotiv wszystkich wypowiedzi. Pojawiały się jednak rozbieżności w ocenie stopnia, w jakim zwrócono uwagę na ekonomikę procesu. W przemowach niektórych radców stanu i członków Trybunatu widać było świadomość pewnych ograniczeń. L.J. Faure konstatował m.in.:

„[...] ustawodawca musi bez wątpienia pilnować, aby ustanowić je [formy A. K.] w jak najbardziej jasny, najbardziej prosty i najmniej kosztowny sposób.

en un mot, la garantie de la propriété et de la sûreté"; Rapport fait par M. Faure..., [w:] op. cit., s. 168 .

16, „[...] serait-elle pas souvent méconnue, si l'on ne traçait pas à l'instruction une marche fixe, et qui présente des garanties contre les erreurs et les surprises?"; Exposé de motifs des livres premier..., s. 2.

${ }^{17}$ „Ce n'est pas dans notre siècle qu'une formalité doit cacher un piège tendu à la bonne foi, et, sous l'empire du génie, les règles seront toujours en accord avec la raison"; Ibidem.

18 „Il est besoin de prévenir les chicanes, l'astuce de ceux qui auraient intérêt à entraver les dispositions de la loi. Des formes trop minutieuses, trop subtiles, trop longues ne conviennent jamais, il faut les élaguer, les bannir, seule la simplicité doit triompher."; Exposé de motifs du troisième..., [w:] op. cit., s. 156.

19 „Oui, messieurs, je vous garantis un code judiciaire net, simple, affranchi de tout verbiage, de toutes formalités inutiles"; Ibidem, s. 157.

${ }^{20}$ „Vous avez [...] simplifié et accéléré la marche de l'instruction”; Rapport fait par M. Albisson, Orateur du Tribunat, au nom de la Section de Législation, sur les Livres III et IV de la première partie du Projet de Code de Procédure Civil, séance du 17 avril 1806, [w:] op. cit., s. 247. 
Jednakże w tym punkcie, jak w całym ludzkim ustawodawstwie, tego, co absolutnie najlepsze, osiągnąć nie sposób”21.

J.B. Treilhard przede wszystkim zgadzał się, że mimo kierowania się przez twórców projektu naczelną zasadą prostoty „kodeks będzie długi”, wyjaśniając, iż „będzie długi wyłącznie dlatego, że będzie kompletny”22. „Jeśli tok działania jest taki prosty, jakim sposobem prawo może być tak obszerne?"23 - pytał sam siebie i - przyznajmy - dość enigmatycznie odpowiadał:

„Instrukcja ta byłaby bardzo krótka, gdyby stawiły się obydwie strony i uczciwie przedstawily swoją sprawę tak, aby dać sędziemu możność orzeczenia. Dlaczego nie zawsze tak się dzieje? Ja z kolei bym się zapytał, dlaczego wszyscy ludzie, ze wszystkich stanów, nie zawsze czynią to, co powinni czynić zgodnie z zasadami konwenansów, sprawiedliwości i obowiązku [...]? Dlaczego beztroska, nieudolność, nieuczciwość, gorycz, nienawiść, dziecinna próżność i chwilowa korzyść, która nie zawsze zgadza się z korzyścią trwałą, tak często i tak silnie wpływają na działanie ludzi?"24

Podkreślić jednak należy, że nigdzie tak naprawdę nie została wyjaśniona objętość kodeksu. W szczególności nie zostało wskazane wprost przeciwdziałanie pieniactwu czy przewlekłości postępowania, a tym bardziej nie wyjaśniono korelacji między długim kodeksem a osiągnięciem tego celu.

Problem, zdaniem J.B. Treilharda, leżał nie w wadliwej technice legislacyjnej, a w ułomnej naturze ludzkiej, w której doszukiwał się on źródła wszelkich przejawów rozwlekłości i skomplikowania procedury:

„Zdumiewa was, Panowie, przerażający obraz owej mnogości poszczególnych incydentów, które mogą wyłonić się w trakcie jakiejś sprawy: mógłbym poszerzyć ramy i uczynić ten obraz jeszcze bardziej przerażającym; zrobiłbym to bez wątpienia, gdybym tylko mógł się łudzić, że zatrzymam na skraju przepaści, nie mówię jakiegoś nieuczciwego procesującego się, bo to niemożliwe, ale choć

${ }^{21}$, ,[...] sans doute, le législateur doit veiller à ce qu'elles soient établies de la manière la plus claire, la plus simple et la moins dispendieuse; mais sur ce point, comme sur toute législation humaine, il est impossible d'atteindre le mieux absolu"; Rapport fait par M. Faure..., [w:] op. cit., s. 168.

22 „Le Code sera long, c'est vrai; mais il ne sera long que parce qu'il sera complet”; Exposé de motifs des livres premier..., [w:] op. cit., s. 5.

${ }^{23}$ „Si la marche est si simple, comment la loi peut-elle être si volumineuse?”; Ibidem, s. 6.

${ }^{24}$, ,[...] cette instruction serait fort courte si les deux parties se présentaient, et si elles exposaient leur affaire de bonne foi pour mettre le juge en état de prononcer. Pourquoi cela n'est-il pas toujours ainsi? Je demanderai à mon tour pourquoi tous les hommes, dans tous les états, ne font-ils pas toujours ce qu'ils devraient faire d'après les règles de convenance, de la justice, du devoir [...]? Pourquoi l'insouciance, l'impéritie, la mauvais foi, l'aigreur, la haine, la puérile vanité et l'intérêt du moment qui n'est pas toujours d'accord avec l'intérêt de tous les jours influent si souvent et si fortement sur les actions des hommes?"; Ibidem, s. 8. 
jednego z owych ludzi, którzy skrupulatnie domagając się wszystkiego, co ich zdaniem im się należy, nie potrafiąc i nie chcąc niczego się zrzec, niezdolni do jakichkolwiek ustępstw ani w tych dużych, ani w tych małych korzyściach, nie przepuszczają ani jednej okazji, by gnać do sądów, i radośnie, w dobrej wierze, godzą się na ruinę siebie oraz własnej rodziny"25.

Jednym z podstawowych zarzutów wobec Code de procédure civil było kopiowanie rozwiązań ordonansu z 1667 r., czyli powrót do tradycji prawnej ancien règime'u. W tym kontekście niebagatelne znaczenie miał fakt, że wszyscy radcowie stanu byli zarazem prawnikami-praktykami, których kariera rozpoczęła się jeszcze przed Rewolucją. Przede wszystkim należy zwrócić uwagę, że czołowa postać wśród twórców i promotorów projektu - Jean Baptiste Treilhard, pełniący od 1802 r. funkcję przewodniczącego Sądu Apelacyjnego w Paryżu, w okresie ancien régime był adwokatem przy tamtejszym Parlamencie. Mimo że w 1789 r. jako deputowany do Stanów Generalnych reprezentował stan trzeci, a następnie został wybrany na przewodniczącego Konstytuanty i Konwentu Narodowego, jawi się jako osoba, która nie miała przekonania do mało realistycznych rewolucyjnych innowacji $\mathrm{w}$ dziedzinie wymiaru sprawiedliwości. Uznawał, co prawda, nadmierną surowość procedury ancien régime'u i rozumiał potrzebę jej złagodzenia, zracjonalizowania i ujednolicenia, nie negował jej jednak jako całości. Stał na stanowisku zachowania z procedury przedrewolucyjnej tego, co najlepsze - czyli większości jej podstawowych zasad i rozwiązań. J.B. Treilhard, broniąc tej metody, zastrzegał, że przejmowanie dawnych instytucji odbywało się z zachowaniem ostrożności i w sposób przemyślany, a nie rutynowy. Głosił: „Przygotowując przedstawione wam prawo musieliśmy chronić się [...] przed tyranią starych przyzwyczajeń, przed którymi nawet najlepszym umysłom tak trudno się bronić"26. Główna linia obrony J.B. Treilharda opierała się wszelako na tezie, iż prawo nie może być oderwanym od rzeczywistości dziełem teoretyków i utopistów, gotowych wychwalać nawet najbardziej radykalne reformy bez sprawdzenia, jak one funkcjonują w praktyce. Konstatował: „Musieliśmy również chronić się przed [...] wybrykami niedoświadczenia, które czasami zbyt szybko skazuje, gdyż nie zawsze potrafi ono zdać sobie sprawę z tego, co

${ }^{25}$ „Vous êtes frappés, messieurs, du tableau effrayant de cette multitude d'incidents particuliers qui peuvent s'élever dans le cours d'une affaire: je pourrais agrandir le cadre et rendre le tableau encore plus effrayant; je l'eusse sans doute fait si j'avais pu me flatter d'arrêter sur le bord du précipice, je ne dis pas un plaideur de mauvaise foi, cela est impossible, mais un seul de ces hommes qui, exigeant rigoureusement tout ce qu'ils pensent leur être dus, ne sachant et ne voulant se relâcher sur rien, incapables d'aucune espèce de capitulation, ni dans le grands, ni dans les petits intérêts, ne manquent pas une occasion de se précipiter dans les tribunaux, et consentent gaiement et de bonne foi à leur ruine et à celle de leur famille"; Ibidem, s. 10 .

${ }^{26}$ „En préparant la loi qui vous est présentée, on a dû se préserver [...] de la tyrannie des veilles habitudes dont même le meilleurs esprits ont tant de peine à se défendre"; Ibidem. 
użyteczne"27. Popierał to stanowisko członek Trybunatu L.J. Faure, zauważając, że: „Nazbyt często doświadczenie własne uczyło narody, jak zgubne w praktyce bywały nawet te najwspanialsze teorie" 28 i dodawał: „Redagując Kodeks wystrzegaliśmy się systemów, woleliśmy raczej skorzystać z lekcji przeszłości, szczególną zaś wagę przywiązywaliśmy do tego, aby zachować to, co było dobre, a usunąc to, co było złe"29. Kodeks został więc zaprezentowany jako reprodukcja przepisów ancien règime z koniecznymi zmianami nawiązującymi do dorobku legislacyjnego z czasów Rewolucji, który nie mógł być pominięty: „Usuwając bezpowrotnie wszystko, co było złe lub tylko bezużyteczne, zachowaliśmy nabożnie wszystko, co było istotne" ${ }^{30}$. Innymi słowy, w toku dyskusji starano się wykazać, że ideami naczelnymi przyświecającymi pracom legislacyjnym były empiria i pragmatyzm, przeciwstawiane dogmatycznym pomysłom tworzenia czegoś ex nihilo, w oderwaniu od rzeczywistości.

J.B. Treilhard zaproponował przy tym dychotomiczny podział na postępowanie procesowe i nieprocesowe, stanowiące podstawę struktury kodeksu:

„Prawo dzieli się na dwie części: w pierwszej znajdziecie normy dotyczące instrukcji spraw w sądach. W drugiej natomiast wytycza się tok działania, którego należy się trzymać w wielu okolicznościach, które pretekstu do debat sądowych mogą nie dawać, lecz w których konieczne jest odwołanie się do autorytetu sędziego" ${ }^{31}$.

W postępowaniu procesowym kładł nacisk na zasadę kontradyktoryjności:

„Zobaczycie, panowie, że wszystkie artykuły tego Kodeksu odwołują się do bardzo prostej zasady. Powód winien wyjaśnić swoje roszczenie, pozwany winien odpowiedzieć; czy sędzia bez tej podwójnej metody mógłby orzekać ze znajomością rzeczy?" 32

27 „On a dû se préserver également [...] des écarts de l'inexpérience trop prompte quelquefois à condamner parce qu'elle ne peut pas toujours se rendre raison de ce qui est bon et utile"; Ibidem, s. 2.

${ }^{28}$ „Les peuples n'ont appris que trop souvent, par leur propre expérience, combien les plus brillantes théories étaient funestes dans la pratique"; Rapport fait par M. Faure..., [w:] op. cit., s. 168.

${ }^{29}$ „En rédigeant le Code [...] on s'est mis en garde contre les systèmes, on a mieux aime profiter des leçons du passé, on s'est attaché particulièrement à conserver ce qui était bien, à retrancher ce qui était mal"; Ibidem.

${ }^{30}$ „En écartant sans retour tout ce qui était mauvais ou seulement inutile, nous avons conservé religieusement tout ce qui était essentiel."; Exposé de motifs des livres premier..., [w:] op. cit., s. 6.

31 „La loi se divise en deux parties: dans la première, vous trouverez les règles de l'instruction des affaires dans les tribunaux; dans la deuxième, on trace la marche à suivre dans beaucoup de circonstances qui peuvent ne pas donner lieu à des débats judiciaires, mas dans lesquels le recours à l'autorité du juge est cependant nécessaire"; Ibidem, s. 5.

32 „Vous verrez, messieurs, que tous les articles de ce Code se rapportent à un principe bien simple. Le demandeur doit expliquer sa prétention, le défendeur doit répondre; sans cette double faculté, comment le juge pourrait-il se prononcer en connaissance de cause?"; Ibidem, s. 6. 


\section{I dodawał:}

„Będziecie mieli sposobność przekonać się, że zawsze byliśmy wierni zapowiedzianej już zasadzie prostoty. Wszystko zawsze sprowadza się do tego, aby nakazać wyjaśnić pozew i wysłuchać obronę" ${ }^{\text {"3 }}$.

W dalszej części swojego wywodu, w uwagach dotyczących tytułu II księgi II poświęconych pozwom, podkreślał:

„Ten, kto jest pozwany do sądu, musi wiedzieć, dlaczego go pozwano, z jakiej przyczyny, do jakiego sądu, o jakiej porze, kto jest adwokatem mającym zajmować się sprawą powoda. Pozew powinien o tym wspominać. Należy upewnić się, że pozwany miał wiedzę o pozwie. W konsekwencji pozew powinien zawierać wzmiankę o nazwisku i zamieszkaniu pozwanego, oraz osoby, która otrzymała kopię"”34.

Obrona uznawana była za prawo naturalne.

J.B. Treilhard był przeciwnikiem nadużywania zasady pisemności $\mathrm{w}$ toku procesu. Składanie pism procesowych podlegało w okresie ancien règime opłatom, co stanowiło pole do licznych nadużyć. $Z$ tego względu projekt stanął na gruncie ustności postępowania i ograniczenia formy pisemnej do absolutnego minimum. J.B. Treilhard wyjaśniał:

„W procedurach zwykłych wielka część spraw, to znaczy wszystkie małej wagi, zostaną wniesione na posiedzenie bez uprzednio spisanej instrukcji. We wszystkich innych procesach [...] jeśli wielka liczba przedstawionych dokumentów i poruszonych pytań może zasługiwać na to, aby sprawa została dopuszczona, żądanie po obydwu stronach będzie zawierać dowody i dokumenty. Nie ma [jednak - A. K.] w takim toku działania niczego, co przypominałoby obszerne instrukcje procesów pisemnych"35.

Sformułowano także zasadę dwuinstancyjności postępowania, która została przedstawiona jako rozwiązanie najbardziej adekwatne, najlepiej wyważające proporcję pomiędzy ekonomiką procesu a potrzebą konwalidacji

${ }^{33}$ „Vous aurez l'occasion de vous convaincre que nous toujours été fideles au principe de simplicité déjà annonce. Tout se réduit toujours à faire expliquer une demande, à entendre la défense [...]"; Ibidem, s. 8.

34 „Il faut bien que celui qui est assigné sache pourquoi il est cité, pour quel motif, à quel tribunal, à quelle époque, quel est l'avoué qui doit occuper pour le demandeur: l'exploit doit le dire. Il faut bien s'assurer que le défendeur a eu connaissance de l'assignation; par conséquent, l'exploit doit faire mention du nom, de la demeure du défendeur et de la personne qui a reçu la copie”; Ibidem, s. 22.

35 „Dans les procédures ordinaires, la grande partie des causes, je veux dire, toutes les affaires sommaires, se porteront à l'audience sans instruction préalablement écrite. Dans toutes les autres causes [...] si le grand nombre de pièces présentées et de questions agitées peut mériter que l'affaire soit mise au rapport, une requête de part et d'autre contiendra les moyens et les pièces. Il n'y a dans cette marche rien qui ressemble aux volumineuses instructions des procès par écrit"; Ibidem, s. 12. 
popełnionych błędów. Koncentrując się na zaletach procedury odwoławczej, członek Trybunatu J. Albisson podkreślał: ,apelacja jako środek zaradczy została wprowadzona nie tylko po to, aby sprostować błędy lub stronniczość pierwszych sędziów, lecz również po to, aby naprawić błędy lub przeoczenia stron i ich obrońców" ${ }^{36}$. Z kolei F.J. Bigot-Préameneu zaznaczał, iż „podporządkowanie pierwszych wyroków apelacji daje gwarancję, że będą one wydawane niezwykle sumiennie i uważnie" 37 .

Obaj mówcy stali jednak na stanowisku, iż dwuinstancyjność powinna być ograniczona tylko do spraw określonej wagi. Dostrzegali też potrzebę stworzenia mechanizmów zapobiegających nadużywaniu procedury odwoławczej. Przeciwdziałaniu pochopnemu i niepotrzebnemu składaniu apelacji służyć miała instytucja zawieszenia, która - według słów F.J. Bigot-Préameneu dawała przegranemu czas na „ochłonięcie” i rozsądne rozważenie sytuacji. „Prawo osiągnie kolejny pożyteczny cel, przeciwstawiając się wielkiej liczbie apelacji, które przypuszczalnie nie mają innej przyczyny jak tylko pierwotny resentyment, zrodzony przez wydanie wyroku" - podkreślat ${ }^{38}$.

Pozostałe instrumenty ograniczające swobodę w składaniu apelacji miały zapobiec nadmiernej przewlekłości postępowania. Z tych względów konieczne było - zdaniem J. Albissona - znaczące skrócenie terminu wniesienia apelacji w stosunku do reguł obowiązujących za czasów ancien règime ${ }^{39}$. Przede wszystkim jednak podkreślano, że zasada dwuinstancyjności powinna być rozumiana ściśle i nie może przeradzać się w bardziej rozbudowany tok procesu. Dążenie to stanowiło reakcję na negatywne doświadczenia z okresu ancien règime' $u, \mathrm{w}$ którym wielość instancji związana była m.in. z istnieniem pionu sądownictwa senioralnego i królewskiego. Jak zaznaczał J. Albisson:

„Zło wzrosło do tego stopnia, że [...] procesujący się nieszczęśnik był skazany na to, aby przebyć aż pięć stopni jurysdykcji, i aby mógł on dojść sprawiedliwości, musiał zaznać najbardziej rażących upokorzeń" ${ }^{40}$.

36 „Le remède de l'appel a été introduit, non seulement pour corriger les erreurs ou la partialité de premiers juges, mais aussi pour réparer les erreurs ou les omissions des parties et leurs défenseurs"; Rapport fait par M. Albisson ..., [w:] op. cit., s. 248.

37 „Subordonner les premiers jugements à l'appel, c'est donner une garantie qu'ils seront rendus avec une plus scrupuleuse attention"; Exposé des motifs des livres troisième et quatrième de la première partie du Code de procédure civile, présentés au Corps Législatif par MM. Bigot-Préameneu, Berlier et Gally, orateurs du Conseil d'État, [w:] op. cit., s. 46.

38 „La loi atteindra encore un but utile en s'opposant à un grand nombre d'appels qui sont présumés n'avoir pour cause que le premier ressentiment qu'une condamnation a fait naître"; Ibidem, s. 53.

${ }^{39} \mathrm{Na}$ mocy ordonansu z $1667 \mathrm{r}$. apelację można było wnieść w przeciągu 3,5 roku w przypadku wezwania przeciwnika do jej wniesienia lub 10 lat, jeśli nie miało ono miejsca. W praktyce okres ten mógł jednak zostać wydłużony nawet do 30 lat.

${ }^{40}$ „Le mal s'accrut au point que [...] un misérable plaideur se voyait souvent condamné à parcourir jusqu'à cinq degrés de juridiction, avoir de pouvoir obtenir justice de la vexation la plus criante"; Rapport fait par M. Albisson..., [w:] op. cit., s. 249. 
Promotorzy rozwiązań kodeksowych w Radzie Stanu i Trybunacie wielokrotnie podkreślali także wagę, jaką przykładali do stworzenia mechanizmów dla właściwej egzekucji orzeczenia. W części I Code de procédure civile zawarta została więc poświęcona wykonywaniu wyroków księga $\mathrm{V}$, stanowiąca przedmiot exposé des motifs radcy stanu P.F. Réala ${ }^{41}$ oraz raportu członków Trybunatu G.J. Favarda ${ }^{42}$ i J. Greniera ${ }^{43}$. Ich uwagi miały w przeważającej mierze charakter techniczny.

Pomiędzy wieloma kwestiami podnoszonymi w exposés des motifs i raportach, chętnie odwoływano się do korzyści, jakie niosło za sobą szersze wykorzystywanie postępowania pojednawczego, wzorowanego na rozwiązaniach zawartych w dekrecie z 16-24 sierpnia 1790 r. ,Jakże zbawienna i filantropijna była myśl, aby dostęp do sądów otwierać dopiero po wyczerpaniu się wszystkich możliwości ugody!"44 - podkreślał J.B. Treilhard. W trakcie prac przygotowawczych nad Code de procédure civile instytucja ta jednak była powszechnie krytykowana z powodu licznych, związanych z jej stosowaniem, nadużyć ${ }^{45}$. Zdawali sobie zresztą z tego sprawę także twórcy uzasadnień i raportów: „Jak to się stało, że tak wspaniała instytucja nie zaowocowała całym dobrem, którego można było po niej oczekiwać, zaś jej efekty w tak niewielkim stopniu spełniły nadzieje?" ${ }^{46}$ Mimo to refleksje na ten temat przedstawione przez J.B. Treilharda i L.J. Faure zdawały się płytkie i rozczarowujące. Ten pierwszy bowiem upatrywał przyczyny niepowodzenia jedynie w stronniczości i nieobiektywności sędziów prowadzących postępowania pojednawcze w okresie Rewolucji. W jego opinii:

„W epoce naszego zamętu [...] nazbyt często byli [oni - A. K.] ludźmi z jakiejś tam partii, a nie ludźmi całego narodu. Zadawano sobie pytanie: jaki kurs repre-

${ }^{41}$ Exposé des motifs du livre $V$ de la première partie du Code de procédure civile, présentés au Corps législatif par M. Réal, orateur du Conseil d'État. Séance du 11 avril 1806, [w:] op. cit., s. 75 i n.

${ }^{42}$ Rapport fait par. M. Favard, orateur du Tribunat, au nom de la section de législation, sur les onze premiers titres du livre $V d u$ Code de procédure civile, relatif à l'exécution des jugements. Séance du 21 avril 1806, [w :] op.cit., s. 269 i n.

${ }^{43}$ Rapport fait par. M. Grenier, orateur du Tribunat, au nom de la section de législation, sur les titres XII, XIII, XIV, XV et XVI du livre V de la première partie du projet de Code de procédure civile. Séance du 21 avril 1806, [w:] op. cit., s. 289 i n.

${ }^{44}$ "Que cette idée était philanthropique et salutaire de n'ouvrir l'accès des tribunaux qu'après l'épuisement de toutes les voies de conciliation!"; Exposé de motifs des livres premier ..., [w:] op. cit., s. 19.

${ }^{45}$ Szerzej na ten temat: J.F. Rauter, Cours de procédure civile française fait à la Faculté de Droit de Strasbourg, Paris 1834, s. 182; H. Bonfils, Traité élémentaire d'organisation judiciaire, de compétence et de procédure en matière civile et commerciale, Paris 1885, s. 358 i n.; E. Garsonnet, C. Cézar-Bru, Précis de procédure civile contenant les matières exigées pour les examens de licence et de capacité, Paris 1904, s. 169; P. Cuche, Manuel de procédure civile et commercial, Paris 1909, s. 309.

46 „Pourquoi faut-il qu'une si belle institution n'ait pas produit tout le bien qu'on pouvait en attendre, et que les effets aient si peu répondu aux espérances?"; Exposé de motifs des livres premier..., [w:] op. cit., s. 19. 
zentuje kandydat? Nigdy zaś nie pytano: czy jest on prawy? Czy jest światły? Czy ma w sobie ową bezstronność, ową odwagę, które powinny cechować sędziego?"47

Radca stanu zdawał się tym samym nie dostrzegać w ogóle problemu w wadliwości mechanizmów instytucjonalnych procedury cywilnej. Nie w takich czy innych ustaleniach kodeksu leżało jego rozwiązanie, a w stworzeniu systemu dopuszczającego do wykonywania zawodu sędziego tylko ludzi z natury odważnych, uczciwych i bezstronnych. Z drugiej zaś strony, inne wypowiedzi świadczą o tym, że w rzeczywistości promotorów projektu cechował brak silnej wiary w ideę koncyliacji, co podkreślały liczne, przytaczane w wystąpieniach J.B. Treilharda i L.J. Faure, wyjątki od wymogu podjęcia próby pojednania.

Nie mniej istotna od sformułowanych w uzasadnieniach czy raportach zasad i refleksji jest analiza kwestii, które zostały pominięte. Przede wszystkim nie sformułowano żadnej teorii dotyczącej istoty procesu cywilnego. Postępowanie cywilne powstało i rozwinęło się przede wszystkim jako proces, który wciąż pozostaje zasadniczym trybem jego postępowania ${ }^{48}$. W ciągu swojej wielowiekowej historii, sięgającej kilku tysięcy lat, był on przedmiotem żywego zainteresowania ze strony światowej nauki prawa konstruującej liczne teorie odnoszące się do jego problematyki, jak choćby stworzona w XIV w. przez Bartolusa de Sexoferrato teoria procesu jako quasi-kontraktu. W uzasadnieniach i raportach do XIX-wiecznego Code de procédure civile opisano natomiast przebieg procesu, jednakże nie odnajdujemy w nich choćby śladu bezpośredniego odwołania się do ówczesnego stanu wiedzy z zakresu procesualistyki.

Zwraca uwagę także zupełne pominięcie w rozważaniach koncepcji tzw. prawa do powództwa ${ }^{49}$, która w nauce procesu cywilnego odgrywała wów-

47, ,...] dans le temps de nos désordres, les magistrats n'étaient que trop souvent les hommes d'un parti et non les hommes de la nation. On se demandait: de quel bord est le candidat? Sans se demander jamais: est-il probe, est-il éclairé? A-t-il cette impartialité, ce courage qui doivent caractériser un magistrat?"; Ibidem, s. 20.

${ }^{48}$ W. Broniewicz, Postepowanie cywilne w zarysie, Warszawa 2008, s. 113.

${ }^{49}$ Koncepcja prawa do powództwa wywodziła się z rozważań nad rzymskim prawem prywatnym, w którym centralną instytucją, szczególnie w procesie formułkowym, była actio, oznaczająca prawo dochodzenia przed sądem swojego roszczenia. Tylko przyznanie actio umożliwiało skierowanie sprawy na drogę sądową. W prawie justyniańskim dokonano systematyzacji actiones, rozwiniętej następnie przez średniowieczną naukę prawa. Również w średniowiecznym angielskim common law dla wszczęcia procesu konieczne było uzyskanie królewskiego zezwolenia, wydawanego jedynie w przypadkach, w których w prawie podmiotowym przewidziana była action. Powstanie szkoły prawa natury zapoczątkowało wyzwalanie się prawa podmiotowego z otoczki, jaką dla niego stanowiła actio, niemniej jednak w nauce i prawie francuskim (inaczej niż w nauce niemieckiej) koncepcja ta jest również współcześnie jednym z centralnych pojęć procesu cywilnego. Szerzej: Ibidem, s. 180. 
czas istotną rolę ${ }^{50}$. Autorzy uzasadnień i raportów z jednej strony odwoływali się do tradycyjnej romanistycznej konstrukcji skargi ${ }^{51}$, z drugiej zaś action (fr.) stosowano w sposób niejednolity i nieprecyzyjny, traktując ją jako synonim różnego rodzaju czynności procesowych ${ }^{52}$. T. Berlier w exposé des motifs do czwartej ustawy z dnia 22 kwietnia 1806 r. zauważył:

„Ludzie, którzy pierwsi zajęli się wielkim i użytecznym projektem nadania Francji Kodeksu cywilnego postanowili włączyć do niego księgę zatytułowaną Des actions, w której procedura została zawarta tak, jak gatunek zawiera się w rodzaju i w której zebrano w całość wszystkie inne sprawy sądowe. [...] sedno myśli przetrwało, i urzeczywistni się dziś poprzez umieszczenie w Kodeksie zwanym proceduralnym wszystkich czynności, nawet takich, które nie konstytuując zasadniczo procesów, mogą dotyczyć urzędu sędziego lub funkcjonariuszy wymiaru sprawiedliwości" ${ }^{53}$.

Niejasne było także pojęcie wyroku. Można co prawda na podstawie wyżej wspomnianych uwag T. Berliera i wystąpienia J.B. Treilharda domniemywać, iż rozróżniali oni orzeczenia wydawane w postępowaniu procesowym i nieprocesowym, niemniej jednak ze względu na brak przybliżenia ogólnej koncepcji, czym w ogóle jest orzeczenie sądowe, dystynkcja ta nabrała charakteru jedynie prostego stwierdzenia faktu. W kontekście tych niedociągnięć nie zaskakuje również, że w Kodeksie, a tym bardziej w exposés i raportach zabrakło powagi rzeczy osądzonej.

Znamienny bowiem $\mathrm{w}$ tej wizji, z pewnością anachronicznej, jest jednak niemalże całkowity brak koncepcji i pojęć stanowiących filary teorii postępowania cywilnego. Niedobór ten w samym Kodeksie można uzasadnić wolą jego twórców, pragnących przede wszystkim uniknąć stworzenia dzieła przeteoretyzowanego: sformułować reguły postępowania, a nie je wyjaśniać. Uzasadnienia ustawy wraz z raportami nie powinny jednak koncentrować się jedynie wokół opisu zawartości Kodeksu i przytaczania zasadniczych celów

${ }^{50}$ We Francji, w przeciwieństwie np. do nauki niemieckiej, nadal ma doniosłe znaczenie. Przyjęto ją expressis verbis m.in. w art. 30 francuskiego kodeksu postępowania cywilnego z $1975 \mathrm{r}$.

${ }^{51}$ Między innymi, Treilhard, akcentując ideę unifikacji postępowania, zaznaczał, iż: „Daleko od nas mgliste subtelności, które w Rzymie dla każdej skargi wprowadziły osobne formuły” („Loin de nous les vagues subtilités qui avaient introduit à Rome des formules particulières pour chaque action.”); Exposé de motifs des livres premier..., [w:] op. cit., s. 1.

${ }^{52}$ M.in. J.B. Treilhard i J. Albisson; op. cit., s. 1 i 261.

53, ,.... [les hommes qui, les premiers, s'étaient occupés du grand et utile projet de donner à la France un Code civil, se proposaient d'y insérer un livre intitulé « Des Actions », dans lequel la procédure eût été comprise comme l'espèce l'est dans le genre et où se fussent réunies toutes les autres actions judiciaires. [...] le fond de la pensée est resté, et va se réaliser aujourd'hui en insérant dans le Code dit de la procédure toutes les actions, même celles qui, sans constituer essentiellement des procès, peuvent intéresser le ministère du juge ou celui des officiers de justice"; Exposé de motifs du livre premier de la deuxième partie du Code de procédure civile présentés au Corps Législatif par M. Berlier, orateur du Conseil d'État. Séance du 12 avril 1806, [w:] op. cit., s. 122. 
jego przyjęcia, a zarysować fundamentalne koncepcje przyświecające twórcom. Milczenie w tym zakresie było niezwykle znamienne, skoro bowiem zabrakło na nie miejsca, zostały tym samym zignorowane, a przyjęta procedura miała raczej charakter doświadczalny.

Argument jednakże o tworzeniu kodeksu przez ,praktyków”, często podnoszony dla wyjaśnienia braku spójnej teorii i filozofii procedury cywilnej, wydaje się zbyt powierzchowny i upraszczający. Problem ten bowiem miał dużo głębsze podłoże, wynikające z miejsca przynależnego kodeksowi jako dodatku do wystawianego na piedestale Code civil. Sytuacja ta zaś stanowiła pokłosie całkowitego odwrócenia relacji pomiędzy prawem materialnym i procesowym w kontekście apoteozy praw podmiotowych. Tradycyjna bowiem rola procedury była pierwszoplanowa. W prawie rzymskim brak było generalnej ochrony procesowej i to jej zindywidualizowane uzyskanie decydowało o posiadaniu uprawnienia. System ten dość swobodnie stosowany był przez pretorów, którzy zależnie od swojej woli niejednokrotnie mogli udzielić tej ochrony nawet w przypadku braku podstawy w obowiązującym przepisie lub też odmówić jej przyznania, w sytuacji, gdy ich zdaniem pomimo istnienia podstawy formalnej roszczenie nie zasługiwało na ochronę ${ }^{54}$. Skarga więc decydowała o faktycznej definicji, rzeczywistym istnieniu i realizacji uprawnienia.

$\mathrm{W}$ okresie ancien règime prymat procedury był nadal faktem ze względu na oblicze ówczesnej rzeczywistości systemu prawnego. Królował, uznawany powszechnie za najważniejszy, ordonans Ludwika XIV o procedurze cywilnej, określany wówczas mianem „Kodeksu cywilnego" „55, którego w zakresie prawa materialnego z różnych względów nie wydano. Zapoczątkowany jednakże przez szkołę prawa natury proces wyzwalania się prawa podmiotowego z otoczki, jaką wcześniej było dla niego actio z jednej strony, z drugiej zaś aura wydarzeń Wielkiej Rewolucji, w kontekście której przebijał się m.in. brak zaufania społeczeństwa do wymiaru sprawiedliwości, sprzeciw wobec samowoli sędziowskiej i politycznego uwikłania parlamentów, szczególnie paryskiego, wpłynęły w konsekwencji na wykształcenie się modelu przeciwnego. Doszło więc do apoteozy prawa materialnego i nadania prawu procesowemu charakteru pomocniczego na zasadzie konieczności realizacji tego pierwszego. I jak widać w exposés i raportach, tak też został zdefiniowany w stosunku do kodeksu z 1804 r. Code de procédure civile.

${ }^{54}$ K. Kolańczyk, Prawo rzymskie, Warszawa 1973, s. 89.

${ }^{55}$ Por. m.in. tytuł komentarza F. Serpillona, Code civil ou Commentaire sur l'Ordonnance du Mois d'Avril 1667, Paris 1776. 